Journal for Educational Research Online Journal für Bildungsforschung Online https://doi.org/10.31244/jero.2021.02.06

Volume 13 (2021), No. 2, 109-131

CC BY-NC-SA 4.o Waxmann 2021

Julia-Carolin Osada \& Hildegard Schaeper

\title{
Individual Characteristics of Teacher Education Students: Re-Examining the Negative Selection Hypothesis
}

\begin{abstract}
Teachers' individual characteristics, such as cognitive and academic abilities, interests, and personality, are considered relevant for their professional competencies, successful teaching, the development of students' competencies, and student achievement. This study re-examined the idea that the teaching profession attracts people with rather unfavorable characteristics, differentiating teaching degrees and study majors. Using extensive data from the German National Educational Panel Study (NEPS; Starting Cohort First-Year Students; $N=8952)$ and multinomial logistic regression, the study investigated whether students' individual characteristics influence the choice of (a) study programs (teacher education vs. other) and (b) teaching degrees (primary and special vs. lower secondary vs. upper secondary education/Gymnasium). The empirical results showed that individual characteristics predict the choice of study programs and teaching degrees and that it is crucial to take into account teacher education students' heterogeneity when investigating teacher education and the teaching profession.
\end{abstract}

\section{Keywords}

teacher education students, individual characteristics, teaching degree, STEM

Dr. Julia-Carolin Osada (corresponding author), University of Vechta, Driverstraße 22, 49377 Vechta, Germany

email: julia-carolin.osada@uni-vechta.de

Dr. Hildegard Schaeper, German Centre for Higher Education Research and Science Studies, Lange Laube 12, 30159 Hannover, Germany

email: schaeper@dzhw.eu 


\section{Individuelle Merkmale von Lehramtsstudierenden: Eine Überprüfung der Negativselektionshypothese}

\section{Zusammenfassung}

Individuelle Merkmale von Lehrkräften, wie kognitive und akademische Fähigkeiten, Interessen und Persönlichkeit, werden als relevant für ihre professionellen Kompetenzen, den Unterrichtserfolg, die Entwicklung der Kompetenzen von Schülerinnen und Schülern und deren Leistungen angesehen. Diese Studie überprüft die Annahme, dass der Lehrkraftberuf Personen mit eher ungünstigen Eigenschaften anzieht und unterscheidet dabei Lehramtstypen und Studienfächer. Anhand umfangreicher Daten aus dem Nationalen Bildungspanel (NEPS; Startkohorte Studierende; $N=8952)$ und multinomialer logistischer Regression wird untersucht, ob individuelle Merkmale von Studierenden mit der Wahl von (a) Studiengängen (Lehramt vs. sonstige) und (b) Lehramtstypen (Grund-/Förderschule vs. Haupt-/Realschule vs. Gymnasium/berufliche Schule) in Zusammenhang stehen. Die empirischen Ergebnisse zeigen, dass individuelle Merkmale die Wahl von Studiengängen und Lehramtstypen vorhersagen und dass die Heterogenität von Lehramtsstudierenden in der Forschung zur Lehrkräftebildung und zum Lehrkraftberuf berücksichtigt werden sollte.

\section{Schlagworte}

Lehramtsstudierende, individuelle Merkmale, Lehramtstypen, MINT-Fächer

\section{Introduction}

\subsection{Teachers' Individual Characteristics and the Impact on Learning and Instruction}

Teachers' cognitive and academic abilities, interests, and personality - in the following referred to as individual characteristics - are considered relevant for their professional competencies, successful teaching, the development of students' competencies, and student achievement (Baier et al., 2018; Roloff Henoch et al., 2015).

However, there exist diverging perspectives on the role of teachers' individual characteristics on learning and instruction (Kunter et al., 2013; Mayr, 2014; Weber et al., 2019): One perspective, known as aptitude approach or bright person hypothesis, assumes that the non-professional and rather stable characteristics with which people enter the teaching profession have a direct impact on teachers' professional behavior, teaching quality, and professional success. Another perspective, known as qualification approach or knowledgeable teacher hypothesis, regards teacher education and the developed profession-specific knowledge as the decisive factor for teacher success. A third approach, the opportunity-use model (Fend, 2008; Helmke, 2012), integrates these two positions. It assumes that the individu- 
al characteristics of teacher education students are relevant as they determine the use of the learning opportunities offered. How learning opportunities are used, in turn, influences the competency development of prospective teachers and, finally, the quality of their teaching and the development of their students' competencies.

Thus, in most of the explanatory models of teaching quality and student learning, individual prerequisites of (prospective) teachers seem to play a certain role. Against this background, we aim to provide further findings on the individual characteristics of future teachers and their impact on the choice of study programs and teaching degrees, using an extensive German data base.

\subsection{Previous Findings on Teachers' Individual Characteristics and the Negative Selection Hypothesis}

Various studies highlighted the relevance of cognitive (ability), conative (motivation, interest), and affective (personality) individual characteristics for learning outcomes and professional behavior (Ackerman \& Beier, 2003; Klusmann, 2013). In the context of teacher education, Eder et al. (2015) emphasized that all three trait complexes lead to a deeper understanding of the choice of different teaching degrees. However, for a long time, abilities, interests, and personality have been considered isolated and rarely as an integrated, explanatory part of the individual (Ackerman \& Beier, 2003).

With regards to teacher quality and its decisive importance for student achievement, motivation, and educational attainment (Roloff et al., 2020) often the question is posed whether the "right" people are attracted by the teaching profession. Additionally, there exist concerns about whether enough high-quality teachers can be attracted in the field of science, technology, engineering, and mathematics (STEM; Roloff Henoch et al., 2015). International research suggested that the profession attracts people with rather unfavorable cognitive and psychological characteristics (negative selection hypothesis; Eder et al., 2015; Guarino et al., 2006; Zumwalt \& Craig, 2008). This question was also examined in Germany. It was found that persons with high cognitive abilities choose the teaching profession less often than other professions, or leave it after a few years (Rothland, 2014). Contrariwise, persons with lower cognitive abilities choose the teaching profession more often (Rothland, 2014).

However, studies taking a differentiated look at teacher candidates in Germany found no proof for a general negative selection when controlling for the teaching degree (Klusmann, 2013; Klusmann et al., 2009; Rothland, 2014) or the field of study (Roloff Henoch et al., 2015). Nevertheless, the studies revealed a certain internal selection within the group of teacher candidates, pointing out their differences in cognitive, motivational, and personal attributes (Brookhart \& Freeman, 1992; Kaub et al., 2012; Neugebauer, 2013; Retelsdorf \& Möller, 2012; Watt et al., 2012). Quite a few studies suggested that candidates for upper secondary education 
show more favorable characteristics than candidates for primary or lower secondary education (Klusmann et al., 2009; Roloff Henoch et al., 2015; Rothland, 2014).

Against this background, further analysis should include teacher candidates' cognitive, conative, and affective characteristics and differentiate the group of teacher education students, taking into account teaching degrees and study majors to re-examine the negative selection hypothesis (Kaub et al., 2012; Roloff Henoch et al., 2015; Rothland, 2014). While the aforementioned studies differentiated teacher education students either by teaching degree or by study major, we are able to take into account both aspects at the same time in our analysis due to an extensive data base from the German National Educational Panel Study. Results of this research make it possible to check common beliefs and everyday theories scientifically and to correct them or, if the negative selection hypothesis is confirmed, to provide stronger advice in the field of teacher recruitment.

\subsubsection{Cognitive and Academic Abilities}

A person's cognitive and academic abilities are seen as the strongest predictors of study success and occupational success (Kaub et al., 2012; Klusmann et al., 2009; Nagy, 2007).

Comparing teacher education students with other university students, Guarino et al. (2006, p. 183) found that in the United States, "college graduates with higher measured academic ability were less likely to enter teaching than other college graduates." In the German context, Spinath et al. (2005) revealed a certain negative selection into the teaching profession for lower secondary education candidates, comparing teacher education students with STEM students. Furthermore, German studies highlighted that upper secondary teacher candidates do not differ substantially from students in non-teaching degree programs (Gold \& Giesen, 1993; Neugebauer, 2013; Retelsdorf \& Möller, 2012).

Comparing different groups of teacher education students, the above-mentioned studies revealed a certain internal selection as candidates for upper secondary education showed better cognitive and academic attributes than candidates for primary and lower secondary education. Klusmann (2013) and Retelsdorf and Möller (2012) observed that candidates preparing for teaching at primary and non-academic secondary schools had significantly poorer school leaving (Abitur) grades than other teacher education students. Analyzing Austrian teacher education students, Eder et al. (2015) made a similar observation, finding that the probability of choosing a teaching career for upper secondary education increased the higher a person's cognitive and academic abilities were. Even though Spinath et al. (2005) discovered that candidates for primary and upper secondary education had similar cognitive and academic profiles, this finding could not be confirmed by other studies. Regarding average school-leaving grades and study performance, candidates for academic secondary education seem to perform best, followed by candidates for 
primary and non-academic secondary education (Gold \& Giesen, 1993; Kaub et al., 2012; Neugebauer, 2013).

\subsubsection{Interests}

In his influential theory of career choice, Holland (1997) distinguished six general types of interest orientation and corresponding environments, known as the RIASEC model (comprising the realistic [Doers], investigative [Thinkers], artistic [Creators], social [Helpers], enterprising [Persuaders], and conventional [Organizers] type; for further definitions, see Wohlkinger et al., 2019). With regards to study and career choice, Holland (1997) highlighted that people choose professional environments that correspond to their individual interest orientations. Several studies showed that this person-environment fit correlates positively with individual and organizational outcomes (for a meta-analysis, see Kristof-Brown et al., 2005; for further details, see section 1.3). Hence, interests seem to play an important role in the choice of degree programs and professions as well as for work engagement, persistence, and professional performance.

Regarding the general interest orientation of teacher education students, various national and international studies found that teacher education students had stronger social interests than other students and predominantly pursued altruistic, service-oriented goals (for the German-speaking area, see König et al., 2013; Roloff Henoch et al., 2015; Rothland, 2014; for the United States and further international comparisons see Brookhart \& Freeman, 1992; Watt et al., 2012). Moreover, it was found that teacher candidates showed lower levels of investigative (Denzler \& Wolter, 2009; Klusmann, 2013; Roloff Henoch et al., 2015), realistic, and conventional interests compared to other university students (Kaub et al., 2012; Klusmann et al., 2009).

Comparing different groups of teacher education students, several studies found that candidates for upper secondary education had lower social, pedagogical interests than candidates for primary and lower secondary education, but higher investigative, subject-related interests (Eder et al., 2015; Neugebauer, 2013; Retelsdorf \& Möller, 2012). Klusmann et al. (2009), moreover, showed that candidates for primary and lower secondary education as well had stronger realistic interests.

\subsubsection{Personality}

Personality is considered to be an important predictor of individual decision-making, successful learning and developmental processes, study success and professional success (Cobb-Clark \& Schurer, 2012; Hanfstingl, 2019).

With regards to the teaching profession and the widespread Big Five model of personality (covering the dimensions extraversion, agreeableness, conscientiousness, neuroticism, openness to experience), studies pointed out significant corre- 
lations between personality traits and professional performance and well-being (Klusmann et al., 2009; Würfl, 2013). According to Würfl (2013) and Mayr and Neuweg (2009), pronounced extraversion is, for example, related to student-centered and communicative teacher behavior. Baier et al. (2018) highlighted that high levels of extraversion support cognitive activation in the classroom.

Looking at the personality of teacher education students, there is no evidence for a general negative selection into the teaching profession. Roloff Henoch et al. (2015) even found that teacher candidates were more extraverted than other students in their sample.

Taking a more differentiated look at teacher education students, German and Austrian studies pointed out that candidates for primary and lower secondary education showed higher levels of extraversion than candidates for upper secondary education (Eder et al., 2015; Klusmann, 2013). Nevertheless, there exist studies that found no statistically significant differences within the group of teacher candidates (Roloff Henoch et al., 2015; Rothland, 2014).

\subsection{Research Questions and Hypotheses}

With the present study, we aim to provide further findings on the individual characteristics of teacher education students and their impact on the choice of study programs and teaching degrees. By analyzing a larger sample and differentiating the group of teacher education students, simultaneously analyzing teaching degree and study major, we go beyond existing studies (e.g., Roloff Henoch et al., 2015) to re-examine the negative selection hypothesis. Regarding teaching degrees, we analyze teacher education students training for primary and special education, lower secondary education (excluding Gymnasium), or upper secondary education (including Gymnasium). Regarding study majors, we differentiate students with at least one STEM major from those with only non-STEM majors.

Conceptually, our study refers to theories of career choice that describe vocational choices as a result of matching personal orientations with the (expected) environment of potential careers (e.g., Holland, 1997). As already mentioned above, people tend to choose a professional environment that corresponds to their personal prerequisites. This person-environment fit is positively related to satisfaction, performance, and persistence in educational and professional contexts (Holland, 1997; Kristof-Brown et al., 2005; Nagy, 2007). Etzel and Nagy (2016) and Li et al. (2013), for example, found that the fit between interests and study major was the strongest predictor of major change intention and positively related to student well-being, academic satisfaction, and performance.

Predictions of study choice from a person-environment fit perspective are compatible with predictions from cost-benefit analyses and the expectancy-value model of Eccles et al. (1983), assuming that "individuals' choice, persistence, and performance can be explained by their beliefs about how well they will do on the activity and the extent to which they value the activity" (Wigfield \& Eccles, 2000, p. 68). 
Therefore, we assume that students choose educational contexts that correspond to their personal prerequisites, leading to a higher subjective expectation of success and to a higher subjective intrinsic value.

Our study addresses two main questions, taking into account the potential heterogeneity of teacher education students compared to other university students (external perspective) as well as within the group of future teachers (internal perspective):

Do students' individual characteristics affect ...

1. the choice of study programs (teacher education vs. other)?

2. the choice of teaching degrees (primary and special vs. lower secondary vs. upper secondary education/Gymnasium)?

Regarding the choice of study programs (external perspective), we know that teacher education is perceived to be less demanding than other study programs (Mayr \& Neuweg, 2009; Retelsdorf \& Möller, 2012). Therefore, students with lower academic abilities may choose teacher education programs instead of other study programs. Moreover, the teaching profession is perceived as a social profession based on interpersonal relationships and communication (Neugebauer, 2013), which might attract extraverted students with pronounced social interests. Against this background, we assumed that regardless of study major, students with lower academic abilities, stronger social interests, and pronounced extraversion more often choose teacher education programs instead of other study programs (Hypothesis 1, H1).

Considering the choice of teaching degrees (internal perspective), the perception of upper secondary education as very demanding (Neugebauer, 2013) might play a role. Consequently, it can be assumed that students with higher academic abilities choose upper secondary education careers rather than primary and special or lower secondary education careers. Moreover, we know that upper secondary education programs focus on research-oriented learning and knowledge transfer, while primary and special as well as lower secondary education programs rather concentrate on pedagogical knowledge and educational support (Retelsdorf \& Möller, 2012). This dichotomy is also reflected in the different curricula, integrating more research-oriented learning into upper secondary education programs and more pedagogical elements into programs for primary and special as well as lower secondary education. Therefore, it is possible that students with stronger investigative interests choose a teaching degree for upper secondary education, whereas students with stronger social interests and pronounced extraversion choose degree programs for primary and special or lower secondary education. Taking into account this potential heterogeneity of teacher education students, we assumed that regardless of study major, students with higher academic abilities and stronger investigative interests more often choose a teaching degree for upper secondary education than for primary and special or lower secondary education. In addition, students with stronger social interests and pronounced extraversion more often 
choose a teaching degree for primary and special or lower secondary education than for upper secondary education (Hypothesis 2, H2).

\section{Method}

\subsection{Participants}

We used data from Starting Cohort First-Year Students of the German National Educational Panel Study (NEPS; Blossfeld et al., 2011). This panel study longitudinally observes a state-wide sample of new entrants to German higher education institutions who enrolled for the first time in winter semester 2010/2011 (Aschinger et al., 2011). Within the randomly drawn sample, teacher education students were oversampled considerably, covering the entire range of teacher training programs. For this paper, we took data from the initial paper-and-pencil questionnaire and the first telephone interview, conducted between winter 2010 and summer 2011 $(N=17910)$, and the second telephone interview, carried out in $2012(N=13113)$.

In our analysis, we included respondents who reported in the initial questionnaire that they had taken up a teacher training course $(N=5172)$. These students were categorized into three groups: students training for (a) primary and special education, (b) lower secondary education (excluding Gymnasium), and (c) upper secondary education (including lower secondary education at a Gymnasium). ${ }^{1}$ As a comparison group, we selected university students in equivalent non-teaching programs $(N=3780)$. Our definition of equivalence was informed by the approach of Roloff Henoch et al. (2015), but is different in two respects. On the one hand, we excluded students enrolled in engineering or computer science, which are almost exclusively studied in non-teaching programs. On the other hand, we included students enrolled in psychology because teacher education students acquire psychological knowledge as well. We also followed Roloff Henoch et al. (2015) in controlling for study major by differentiating students with at least one STEM study major from those with only non-STEM majors. As already mentioned, there are currently concerns about good STEM teachers (Roloff Henoch et al., 2015). Another reason for the distinction between STEM and non-STEM majors lies in the fact that previous research revealed clear differences in the individual characteristics of STEM and non-STEM students (Roloff Henoch et al., 2015). Table 1 gives an overview of the composition of the sample used in this study.

1 Teacher training tracks that span several educational levels were subsumed under the highest level. 
Table 1: Sample Composition

\begin{tabular}{lcccccc}
\hline & \multicolumn{2}{c}{ STEM } & \multicolumn{2}{c}{ Non-STEM } & \multicolumn{2}{c}{ Total } \\
\cline { 2 - 7 } Degree program & $N$ & $\begin{array}{c}\% \\
\text { female }\end{array}$ & $N$ & $\begin{array}{c}\% \\
\text { female }\end{array}$ & $\begin{array}{c}\text { \% } \\
\text { female }\end{array}$ \\
\hline Teaching: primary \& special education & 303 & 89 & 825 & 89 & 1128 & 89 \\
Teaching: lower secondary education & 420 & 79 & 609 & 84 & 1029 & 82 \\
Teaching: upper secondary education & 1102 & 63 & 1913 & 74 & 3015 & 70 \\
Other university degree programs & 1237 & 51 & 2543 & 75 & 3780 & 67 \\
\hline Total & 3062 & 63 & 5890 & 78 & 8952 & 73 \\
\hline
\end{tabular}

Note. 206 cases excluded because of missing data on the cluster information variable.

\subsection{Measures}

The dependent variable reflects the choice of different teacher education programs and non-teaching university courses and distinguishes four categories, which are described in Table 1. Since various studies emphasized the relevance of certain individual characteristics for understanding the choice of different teaching degrees and person-environment fit theory assumes that vocational choices are a result of matching personal orientations with (expected) environments of potential careers, we selected academic abilities, interests, and personality factors as predictors of educational choices and characteristics of different groups of students, controlling for socio-demographic factors.

We took the grade point average (GPA) obtained in the Abitur (German school leaving certificate qualifying for higher education) as an indicator for academic abilities. The Abitur GPA can also be considered as a proxy for cognitive abilities because it has high predictive validity for university grades (Trapmann et al., 2007) and correlates considerably with teacher education students' (pedagogical) content knowledge (Krauss et al., 2017; Lindl \& Kloiber, 2017). With regards to educational choices, it should be noted that the effect of Abitur grades does not necessarily indicate processes of self-selection, but also results from selection by others. The variable takes on values between 1 (very good) and 4 (sufficient).

To measure general interest orientation, the NEPS used a short 18-item instrument that covers the six dimensions of Holland's (1997) RIASEC model (Wohlkinger et al., 2019). The dimensions were measured by three items each. Because of rather low values of Cronbach's alpha for enterprising and conventional interests, we only examined realistic $(\alpha=.63)$, investigative $(\alpha=.65)$, artistic $(\alpha=.60)$, and social interests $(\alpha=.69)$. The scales entered the analysis as composite scores (mean of the respective variables with non-missing values) ranging from 1 (very little interest) to 5 (very strong interest).

According to often used thresholds, the alpha values might be considered questionable. However, in the original sample the internal consistency is more satisfying (realistic: $\alpha=.70$; investigative: $\alpha=.62$; artistic: $\alpha=.62$; social: $\alpha=.73$ ) and 
explorative factor analysis (iterated principal factor method with promax rotation) yielded a clear factor pattern with a simple structure corresponding to the postulated measurement model. In addition, it should be noted that alpha is very sensitive to the number of items in a scale (Yang \& Green, 2011) and that our scales consist of only three items each. Nonetheless, the fact remains that some variables constituting a factor had low loadings. A closer inspection of the item wording revealed that the items measure distinct aspects of a broader construct, which must not necessarily correlate (e.g., the social interest items "reading or interpreting poetry/literature" and "drawing pictures"; the wording for all items can be found in Leibniz Institute for Educational Trajectories, 2014; Leibniz-Institut für Bildungsverläufe e.V., 2014), and that, therefore, they might be considered to be formative rather than reflective measures (for this distinction, see Christophersen \& Grape, 2009). An adequate way of dealing with formative indicators is index construction by computing the (weighted) sum of the variables or - as we did - averaging the sum (Latcheva \& Davidov, 2019).

The Big Five personality traits were assessed by a short 11-item operationalization developed by Rammstedt and John (2007). Since the reliability of most of the factors was quite low, we focused on extraversion, which was measured by two items (one true-scored and one false-scored; $r=-.61$ ). We included the scale as a composite variable, ranging from 1 (very low/weak) to 5 (very high/strong).

Social determinants of educational decisions are not the focus of our present study. However, some of these factors are known to affect the choice of teacher training. Therefore, we controlled for gender ( $0=$ male; $1=$ female $)$, parents' education ( $\mathrm{o}=$ no parent with a degree; $1=$ at least one parent with a degree), and migration background (one dummy variable indicating first-generation and second-generation migrants; reference category: third generation or no migration background). In addition, we took into account that admission to particular degree courses depends on the Abitur grades (Numerus clausus, NC). Therefore, we included the information as to whether the admission was based on the final grade of the university entrance qualification $(0=$ no $; 1=$ yes $)$ as a control variable. This data was collected in the initial paper-and-pencil questionnaire.

\subsection{Analytical Strategy}

We used multinomial logistic regression to estimate the effects of individual characteristics on the choice of study programs and teaching degrees. We controlled for study major by conducting the analysis separately for STEM and non-STEM majors. As we are not only interested in comparing the choice of different teacher education programs with the decision for other university programs, we present the estimates for all possible pairs of outcome categories.

We report odds ratios because we seek to contrast the different categories of a multinomial response variable and to analyze the dynamics among various educational choices. Under these circumstances, odds ratios are more suitable than av- 
erage marginal effects (Long \& Freese, 2014). Odds ratios represent the factor by which the odds of one outcome versus another outcome are expected to change for a unit change in the predictor. Values smaller than 1.00 indicate a decrease in the odds (a negative effect), values greater than 1.00 an increase (a positive effect; Long \& Freese, 2014).

With one exception (information on admission restrictions, i.e., NC: $17.8 \%$ missing values in the sample used for analysis), non-response on the explanatory variables measured in the first panel wave was ignorable (Abitur grades: $1.8 \%$; variables measuring interest orientation: up to $0.1 \%$; parents' education: $0.2 \%$ ) or not present (gender, migration background). However, information on the Big Five personality factors was collected in the second telephone interview and, therefore, affected by panel dropout. Because panel attrition was considerable and the two items measuring extraversion had $25.1 \%$ missing values in the sample used for analysis, we imputed the missing data using multiple imputation (MI) methods.

MI requires that the data are missing at random (MAR), that is, the probability of a particular variable being missing depends on other observed variables but not on the values of the particular variable or any other unobserved variable (Enders, 2010; Graham 2012). If the data are MAR, complete case analysis (aka listwise deletion) yields biased estimates while imputed data can produce unbiased estimates (Enders, 2010).

Unfortunately, it cannot be tested whether the missing data mechanism is MAR, unless follow-up data from non-respondents are available (Enders, 2010; Schafer \& Graham, 2002). Regarding the NC variable, we are confident that MAR holds. Non-response on this variable resulted from intentionally shortening the survey program by skipping several less important questions for those who did not receive the initial paper-and-pencil questionnaire in the later recruitment phase but were directly interviewed via telephone (details of the recruitment process are given in Steinwede \& Aust, 2012). There is no indication that the mode of recruitment depends on the value of the NC variable. Regarding the extraversion items, we know from non-response analyses that panel attrition is substantively related to gender, parents' education, migration history, competencies, age, and enjoying studying (Zinn et al. 2016). All these variables were included in the imputation model so that missing not at random (MNAR) data might have been effectively converted to MAR (Enders, 2010; Lüdtke et al., 2007; Schafer \& Graham, 2002). Even if we falsely assume MAR and the data are MNAR, MI is superior over ad hoc missing data techniques such as listwise deletion and produces acceptable estimates, unless the causes of missingness are strongly correlated with outcomes (Collins et al. 2001; Lüdtke et al., 2007). Taking these arguments together, we concluded that imputation is to be preferred over listwise deletion.

We applied multiple imputation by chained equations (MICE) using the statistical software Stata, version 14. Following the rule of thumb that the number of imputations should be at least equal to the fraction of missing information (Graham et al., 2007; White et al., 2011), we generated 30 data sets. As recommended by White et al. (2011), we used all variables of the analysis model in the imputation 
model. As mentioned above, we additionally included auxiliary variables assumed or known to influence the missing data mechanism (school grades in mathematics and German, enjoyment of studying, subjective likelihood of successfully completing the degree course, age, children at Wave 1).

In NEPS Starting Cohort First-Year Students a complex sampling design was realized using cluster sampling, stratification, and unequal probabilities of selection (Aßmann et al., 2011). To get correct point estimates and standard errors, we used sampling weights and took the clustering of the data into account.

Stata does not report pseudo $R^{2}$ values when fitting a logit model to multiply imputed data. To get an idea of the explanatory power of the full models, we estimated the logit models for each of the 30 datasets and computed the average pseudo $R^{2}$ (McFadden).

\section{Results}

\subsection{Academic Abilities}

Based on previous research, we assumed that students with lower academic abilities will more often choose teacher training instead of other programs, regardless of their study major (H1). In addition, we put forward the hypothesis that students with higher academic abilities more often choose a teaching degree for upper secondary education than for primary and special or lower secondary education (H2). 
Table 2: Multinomial Logit Model for the Choice of Degree Program Within STEM Majors (Odds Ratios)

\begin{tabular}{|c|c|c|c|c|c|c|}
\hline \multirow[b]{3}{*}{ Predictor } & \multicolumn{6}{|c|}{ STEM majors $(N=3062)$} \\
\hline & \multicolumn{3}{|c|}{ External perspective } & \multicolumn{3}{|c|}{ Internal perspective } \\
\hline & 1 vs. 4 & 2 vs. 4 & 3 vs. 4 & 1 vs. 2 & 1 vs. 3 & 2 vs. 3 \\
\hline \multicolumn{7}{|l|}{ Academic abilities } \\
\hline Abitur grades & 1.42 & $3.25^{* *}$ & 0.90 & $0.44^{* * *}$ & 1.58 & $3.61^{* *}$ \\
\hline \multicolumn{7}{|l|}{ Interests } \\
\hline Realistic & 1.11 & 1.15 & 1.17 & 0.96 & 0.95 & 0.98 \\
\hline Investigative & $0.28^{* *}$ & $0.38^{* *}$ & $0.50^{* * *}$ & $0.73^{* *}$ & $0.56^{* *}$ & $0.76 * *$ \\
\hline Artistic & $1.39^{* *}$ & 1.21 & $1.22 * *$ & 1.15 & 1.15 & 0.99 \\
\hline Social & $4.52^{* *}$ & $3.31^{* * *}$ & $2.44^{* * *}$ & $1.37^{*}$ & $1.85^{* * *}$ & $1.35^{* * *}$ \\
\hline \multicolumn{7}{|l|}{ Personality } \\
\hline Extraversion & 1.22 & $1.48^{* *}$ & $1.41^{* *}$ & 0.82 & 0.86 & 1.05 \\
\hline \multicolumn{7}{|l|}{ Controls } \\
\hline Parents' education: degree & $0.68 *$ & $0.56^{* *}$ & $0.74 *$ & 1.22 & 0.92 & $0.75^{*}$ \\
\hline Gender: female & $3.40^{* * *}$ & $2.46^{* * *}$ & 1.11 & 1.38 & $3.07^{* * *}$ & $2.22 * *$ \\
\hline Migrants & $0.43^{* *}$ & 0.63 & $0.60^{* *}$ & 0.68 & 0.72 & 1.05 \\
\hline Numerus clausus (NC) & $16.00^{* * *}$ & 2.32 & 1.44 & $6.89^{* * *}$ & $11.10^{* *}$ & 1.61 \\
\hline Intercept & 0.00 & 0.00 & 0.02 & 0.81 & 0.00 & 0.01 \\
\hline $\begin{array}{l}\text { Average pseudo } R^{2} \\
\text { (McFadden) }\end{array}$ & & & & & & \\
\hline
\end{tabular}

Note. Degree programs: 1 = Teaching: primary \& special education; 2 = Teaching: lower secondary education; 3 = Teaching: upper secondary education; 4 = Other university degree programs. ${ }^{*} p<.05 .{ }^{* *} p<.01$.

Our findings, presented in Table 2 (for STEM majors) and Table 3 (for non-STEM majors), partially support and partially contradict our hypotheses. H1 is supported as poor Abitur grades reduced the likelihood of choosing non-teaching programs over teacher education for the lower secondary level (column 2 vs. 4). However, a negative selection into teacher training could not be observed regarding teacher education for primary and special schools (column 1 vs. 4) and upper secondary education (column 3 vs. 4). Independent of the study major, the likelihood of choosing these programs over comparable non-teaching university programs was not significantly affected by students' Abitur grades. 
Table 3: Multinomial Logit Model for the Choice of Degree Program Within Non-STEM Majors (Odds Ratios)

\begin{tabular}{|c|c|c|c|c|c|c|}
\hline \multirow[b]{3}{*}{ Predictor } & \multicolumn{6}{|c|}{ Non-STEM majors $(N=5890)$} \\
\hline & \multicolumn{3}{|c|}{ External perspective } & \multicolumn{3}{|c|}{ Internal perspective } \\
\hline & 1 vs. 4 & 2 vs. 4 & 3 vs. 4 & 1 vs. 2 & 1 vs. 3 & 2 vs. 3 \\
\hline \multicolumn{7}{|l|}{ Academic abilities } \\
\hline Abitur grades & 1.26 & $2.91 * *$ & 0.89 & $0.43^{* * *}$ & $1.42^{* *}$ & $3.28 * *$ \\
\hline \multicolumn{7}{|l|}{ Interests } \\
\hline Realistic & $1.36^{* *}$ & $1.44^{* *}$ & $1.21 * *$ & 0.95 & 1.12 & $1.19 *$ \\
\hline Investigative & $0.66 * *$ & $0.67^{* *}$ & $0.70^{* * *}$ & 0.99 & 0.94 & 0.95 \\
\hline Artistic & 1.05 & 0.98 & 1.08 & 1.06 & 0.97 & 0.91 \\
\hline Social & $2.79 * *$ & $1.88 * *$ & $1.58 * *$ & $1.48^{* * *}$ & $1.76^{* * *}$ & $1.19 *$ \\
\hline \multicolumn{7}{|l|}{ Personality } \\
\hline Extraversion & 1.11 & $1.34^{* *}$ & $1.39^{* * *}$ & $0.83^{*}$ & $0.80^{* * *}$ & 0.97 \\
\hline \multicolumn{7}{|l|}{ Controls } \\
\hline Parents' education: degree & $0.79 *$ & $0.55^{* *}$ & 0.85 & $1.44^{*}$ & 0.93 & $0.65^{* *}$ \\
\hline Gender: female & $1.83^{* *}$ & $1.70^{* *}$ & $0.71 *$ & 1.08 & $2.58 * *$ & $2.40 * *$ \\
\hline Migrants & $0.45^{* *}$ & 0.76 & 0.76 & $0.59 *$ & $0.58 * *$ & 0.99 \\
\hline Numerus clausus (NC) & $21.39^{* *}$ & 0.89 & 0.88 & $24.09^{* *}$ & $24.41^{* * *}$ & 1.01 \\
\hline Intercept & 0.00 & 0.00 & 0.02 & 0.24 & 0.00 & 0.01 \\
\hline $\begin{array}{l}\text { Average pseudo } R^{2} \\
\text { (McFadden) }\end{array}$ & & & & & & \\
\hline
\end{tabular}

Note. Degree programs: 1 = Teaching: primary \& special education; 2 = Teaching: lower secondary education; 3 = Teaching: upper secondary education; 4 = Other university degree programs ${ }^{*} p<.05 .{ }^{* *} p<.01$.

Regarding the internal selection hypothesis (H2), we found a strong negative selection into teacher education programs for lower secondary education. The poorer the Abitur grades, the higher the likelihood of being enrolled in a track for lower secondary education instead of tracks for primary and special (column 1 vs. 2) or upper secondary education (column 2 vs. 3). Significant differences between teacher candidates for primary and special education and for upper secondary education could only be observed in the group of students with non-STEM majors. Thus, according to our results on the impact of Abitur grades, H2 holds by and large only insofar as teacher education students for the lower secondary track have worse Abitur grades than other teacher candidates.

This finding parallels the results of Spinath et al. (2005) but contradicts other studies, which found that teacher candidates for primary education had poorer Abitur grades than students preparing for upper secondary education. Possible reasons for these discrepancies might be differently defined comparison groups, 
changes regarding admission requirements or different samples, partly limited to a single federal state or a small number of institutions. Another reason lies in the fact that we considered the clustering of the data.

\subsection{Interests}

In line with previous research, our results show that teacher education programs attract students with high social interests whereas students with high investigative interests more often choose non-teaching university programs - hence confirming H1. The effects were significant for each of the three teacher training programs (as opposed to other university programs) and both students with and without a STEM major. For non-STEM students, the effects were weaker.

For the STEM group, we also observed differences between the different teaching degree programs: High investigative interests decreased the odds of choosing teacher education for primary and special schools instead of teacher training at the lower secondary level $(O R=0.73$; column 1 vs. 2 in Table 2$)$ or at the upper secondary level ( $O R=0.56$; column 1 vs. 3$)$. Additionally, a unit increase of investigative interests decreased the odds of deciding in favor of teacher training for lower secondary education over teacher training for upper secondary education by $26 \%$ $(O R=0.74$; column 2 vs. 3$)$. In other words, the four groups of STEM students can be ranked according to their investigative interests as follows: teacher candidates for primary and special education, teacher candidates for lower secondary education, future teachers at the upper secondary level, and, at the top, students in non-teaching university courses. However, as far as non-STEM students are concerned, we did not find an internal differentiation of teacher candidates according to investigative interests. Thus, in case of investigative interests $\mathrm{H} 2$ is supported for STEM students but has to be rejected for non-STEM students.

Regarding social interests, our study provided empirical evidence in favor of both $\mathrm{H} 1$ and H2: The higher the social interests were, the more likely students were to opt for teacher training instead of non-teaching university programs. Social interests also affected the choice of different teaching careers: The odds in favor of teacher training for primary and special education instead of lower secondary or upper secondary education increased with higher social interests. Higher social interests also increased the likelihood of choosing a teaching career for lower secondary education instead of upper secondary education. This finding applied to STEM students as well as to non-STEM students. However, the effects were stronger for STEM students. To put it differently, teacher candidates for primary and special education reported the highest level of social interests, followed by future teachers at the lower secondary level, teacher training students for upper secondary education, and students in non-teaching university programs.

Compared to investigative and social interests, the other interest dimensions were less predictive of study choice. For non-STEM students, realistic interests significantly increased the likelihood of being enrolled in a teacher education pro- 
gram instead of a non-teaching university degree course (see Table 3). For STEM students, artistic interests played a role when deciding to enter a teacher education program for primary and special or upper secondary education rather than a non-teaching university program (see Table 2).

These findings partly contradict previous research. While Roloff Henoch et al. (2015) did not observe an effect for artistic interests, we found artistic interests to be predictive of choosing different degree programs in the case of STEM majors. This can be explained by the fact that teacher candidates study more than one teaching subject and often a STEM and a non-STEM major are combined. In some teacher training tracks and some federal states, students are even obliged to take one subject from the STEM field. Contrary to our results, Roloff Henoch et al. (2015) reported that the odds in favor of teacher education increased with lower realistic interests when looking at students with STEM study majors. No effect was found for students with non-STEM majors. One reason for these differences lies in the fact that we used distinct definitions of STEM and non-STEM majors and that we excluded engineering and computer science, that is, STEM subjects that are almost exclusively offered by non-teaching degree programs.

\subsection{Personality}

Regarding personality factors, our analysis shows that the likelihood of preferring teacher education for lower and upper secondary education over non-teaching university programs increased with higher levels of extraversion, both within the group of STEM and non-STEM students (see Table 2 and Table 3). The coefficient for teacher education for primary and special education vs. non-teaching programs was not significant in the full model but was significant in models without other predictors. The differences between the different teacher education tracks were not pronounced and did not show a clear pattern. Our results corroborate earlier findings and agree with $\mathrm{H} 1$.

As already said, social determinants of educational decisions are not the focus of our study. Nonetheless, some findings are worth being mentioned. In line with previous research (Neugebauer, 2013), our analysis yields the result that teacher education is more often chosen by females and less often by students with a higher educational background or a migration history. Females, in addition, more often than males prefer teacher education tracks for primary, special, and lower secondary education over upper secondary careers. However, when it comes to the choice between teacher education for upper secondary education and non-teaching university programs, women do not necessarily favor teacher training courses more strongly than men.

The explanatory power of the full regression models with all predictors included varied depending on study majors. The set of independent variables was more predictive for students with STEM majors (average pseudo $R^{2}[\mathrm{McFadden}]=.21$ ) than 
for those with non-STEM majors (average pseudo $R^{2}$ [McFadden] = .11). A similar result was found by Roloff Henoch et al. (2015).

\section{Discussion}

\subsection{New Insights Into Teacher Education Students' Individual Characteristics}

Previous research has considerably increased our knowledge on factors influencing the choice of teacher training and on characteristics of teacher education students. However, due to limitations in sample size or sample composition, most of these studies could not adequately deal with the complexity of educational decisions. Against this background, we re-examined the so-called negative selection hypothesis, analyzing newly available data for Germany. On the one hand, our study used the approach of Roloff Henoch et al. (2015) as a reference model as we defined adequate comparison groups and controlled for the field of study, differentiating STEM and non-STEM students. On the other hand, our study went beyond previous research as we finely differentiated the group of teacher education students according to three types of teaching degrees and simultaneously analyzed the type of degree and field of study. This procedure allowed us to account for the considerable heterogeneity of teacher candidates in terms of teaching track and subjects.

Due to the differentiated approach, we were able to gain new insights. In terms of academic abilities (Abitur grades), we found no general negative selection into teacher training. But we observed a negative selection for lower secondary education degrees - both for STEM and non-STEM majors.

Regarding students' interests, our study showed that students with high social interests more often chose teacher education programs whereas students with high investigative interests more often chose non-teaching university programs. Comparing the different teaching tracks, social interests were most pronounced in tracks for primary and special education, followed by lower secondary and upper secondary education, whereas candidates for upper secondary education with STEM majors showed stronger investigative interests than comparable candidates for lower secondary or primary and special education. Thus, social and investigative interests seem to be predictive of study choice, which is in line with prior studies and rational because the teaching profession is social and pedagogical, especially when it comes to working at primary and special or lower secondary schools.

In terms of personality traits and regardless of the chosen study major, our analysis shows that students with high levels of extraversion preferred teacher education over non-teaching degree programs. These results corroborate earlier findings and indicate a positive selection into the teaching profession regarding this personality factor. 
All in all, we can conclude that there seems to be a systematic association between students' individual characteristics and their choice of study programs and teaching degrees. In line with the person-environment fit approach, students' educational choices seem to match their abilities, interests, and personality, which is, in our view, a positive finding with regard to students' and prospective teachers' well-being and future successful teaching. As opposed to previous findings, we found no general negative selection into teacher education when controlling for teaching degrees and the field of study.

\subsection{Limitations, Future Research, and Practical Implications}

As with many other studies on teacher recruitment, our analysis is affected by the limitation that the individual characteristics were only measured after taking up higher education, which makes it necessary to assess our results carefully in terms of selection or socialization effects (Roloff Henoch et al., 2015). However, in our case, students' interests were measured shortly after entering university.

Another limitation refers to the admission requirements, as we were not able to control for the minimum grade requirements, as well as to the rather low reliability and internal consistency of the scales used to measure general interest orientation. When the indicators can be considered to be formative, low values of Cronbach's alpha are to be expected. However, in formative measurement models all indicators that form a construct should be included (Bollen \& Lennox, 1991). "Omitting an indicator is omitting a part of the construct” (Bollen \& Lennox, 1991, p. 308). In the NEPS, the requirement of a comprehensive measurement is not met. Although our results are plausible and consistent with previous research, we, therefore, cannot be sure whether they hold when using other measures for general interest orientation.

A certain challenge when comparing prospective teachers and other students is that the findings strongly depend on the definition and delimitation of subject areas. We tried to meet this challenge by including only those subject areas that can be studied by teacher candidates and other university students or that are chosen by a substantial proportion of both comparison groups. However, we must be aware that our definition may not be appropriate in future research. This will be the case, for example, when economics and computer science gain a greater role in German school curricula.

We found evidence for a systematic association between certain individual characteristics of higher education students and educational choices. However, we did not examine the impact of individual prerequisites on skill development, degree completion, and professional success. Although some research has been done in this field, the topic remains under-examined. Therefore, an important task for future research is to further investigate the consequences of individual characteristics for the use of learning opportunities, the development of competencies, and the quality of instruction (Kaub et al., 2012; Rothland, 2014). This might as well shed 
new light on the diverging perspectives on the role of teachers' characteristics, as mentioned in section 1.1.

All in all, it seems to be crucial for researchers as well as for educational policymaking and policy implementation to take into account teacher education students' heterogeneity. Reflecting on individual motivations, prerequisites, and institutional conditions at an early stage of teacher training or even before taking up teacher training might be helpful to enhance recruitment processes and to foster study success, job satisfaction, and retention in the teaching profession (see also Watt et al., 2012).

\section{Acknowledgments}

This paper uses data from the National Educational Panel Study (NEPS; Starting Cohort First-Year Students; doi:10.5157/NEPS:SC5:9.0.o). From 2008 to 2013, NEPS data was collected as part of the Framework Program for the Promotion of Empirical Educational Research funded by the German Federal Ministry of Education and Research (Bundesministerium für Bildung und Forschung, BMBF). As of 2014, NEPS is carried out by the Leibniz Institute for Educational Trajectories (LIf$\mathrm{Bi}$ ) at the University of Bamberg in cooperation with a nationwide network.

The work on this paper was supported by funds of the German Federal Ministry of Education and Research, grant number B1014. The authors are responsible for the content of the article.

\section{References}

Ackerman, P. L., \& Beier, M. E. (2003). Intelligence, personality and interests in the career choice process. Journal of Career Assessment, 11(2), 205-218. https://doi. org/10.1177/1069072703011002006

Aschinger, F., Epstein, H., Müller, S., Schaeper, H., Vöttiner, A., \& Weiß, T. (2011). Higher education and the transition to work. In H.-P. Blossfeld, H.-G. Roßbach, \& J. von Maurice (Eds.), Education as a lifelong process: The German National Educational Panel Study (NEPS) (pp. 267-282). VS Verlag für Sozialwissenschaften. https://doi.org/10.1007/s11618-011-0190-7

Aßmann, C., Steinhauer, H. W., Kiesl, H., Koch, S., Schönberger, B., Müller-Kuller, A., ... Blossfeld, H.-P. (2011). Sampling designs of the National Educational Panel Study: Challenges and solutions. In H.-P. Blossfeld, H.-G. Roßbach, \& J. von Maurice (Eds.), Education as a lifelong process: The German National Educational Panel Study (NEPS) (pp. 51-65). VS Verlag für Sozialwissenschaften. https://doi.org/10.1007/s11618-011-0181-8

Baier, F., Decker, A.-T., Voss, T., Kleickmann, T., Klusmann, U., \& Kunter, M. (2018). What makes a good teacher? The relative importance of mathematics teachers' cognitive ability, personality, knowledge, beliefs, and motivation for instructional quality. British Journal of Educational Psychology, 88(4), 767-786. https://doi. org/10.1111/bjep.12256

Bollen, K. A., \& Lennox, R. (1991). Conventional wisdom on measurement: A structural equation perspective. Psychological Bulletin, 110(2), 305-314. https://doi. org/10.1037/0033-2909.110.2.305 
Blossfeld, H.-P., Roßbach, H.-G., \& von Maurice, J. (Eds.). (2011). Education as a lifelong process: The German National Educational Panel Study (NEPS). VS Verlag für Sozialwissenschaften.

Brookhart, S. M., \& Freeman, D. J. (1992). Characteristics of entering teacher candidates. Review of Educational Research, 62(1), 37-6o. https://doi.org/10.3102/ 00346543062001037

Christophersen, T., \& Grape, C. (2009). Die Erfassung latenter Konstrukte mit Hilfe formativer und reflektiver Messmodelle [Measuring latent constructs using formative and reflective measurement models]. In S. Albers, D. Klapper, U. Konradt, A. Walter, \& J. Wolf (Eds.), Methodik der empirischen Forschung (3rd ed., pp. 103118). Springer. https://doi.org/10.1007/978-3-322-96406-9_8

Cobb-Clark, D., \& Schurer, S. (2012). The stability of big-five personality traits. Economics Letters, 115(1), 11-15. https://doi.org/10.1016/j.econlet.2011.11.015

Collins, L. M., Schafer, J. L., \& Kam, C.-M. (2001). A comparison of inclusive and restrictive strategies in modern missing data procedures. Psychological Methods, 6(4), 330-351. https://doi.org/10.1037/1082-989X.6.4.330

Denzler, S., \& Wolter, S. C. (2009). Sorting into teacher education: How the institutional setting matters. Cambridge Journal of Education, 39(4), 423-441. https://doi. org/10.1080/03057640903352440

Eccles, J., Adler, T. F., Futterman, R., Goff, S. B., Kaczala, C. M., Meece, J. L., \& Midgley, C. (1983). Expectancies, values, and academic behaviors. In J. T. Spence (Ed.), Achievement and achievement motives: Psychological and sociological approaches (pp. 75-146). Freeman.

Eder, F., Dämon, K., \& Hörl, G. (2015). Universität oder Pädagogische Hochschule? Persönlichkeitsmerkmale als Prädiktoren für Niveau-Entscheidungen im Lehramtsstudium [University or college of education? Personality traits as predictors of level-decisions in teacher education]. Zeitschrift für Bildungsforschung, 3, 3-25. https://doi.org/10.1007/s35834-013-0051-y

Enders, C. K. (2010). Applied missing data analysis. Guilford Press.

Etzel, J. M., \& Nagy, G. (2016). Students' perceptions of person-environment fit: Do fit perceptions predict academic success beyond personality traits? Journal of Career Assessment, 24(2), 270-288. https://doi.org/10.1177/1069072715580325

Fend, H. (2008). Neue Theorie der Schule: Einführung in das Verstehen von Bildungssystemen [New theory of schooling: Introduction to understanding educational systems] (2nd ed.). VS Verlag für Sozialwissenschaften.

Gold, A., \& Giesen, H. (1993). Leistungsvoraussetzungen und Studienbedingungen bei Studierenden verschiedener Lehrämter [Performance requirements and study conditions among students of different teaching degrees]. Psychologie in Erziehung und Unterricht, 4O(2), 111-124.

Graham, J. W. (2012). Missing data: Analysis and design. Springer. https://doi. org/10.1007/978-1-4614-4018-5

Graham, J. W., Olchowski, A. E., \& Gilreath, T. D. (2007). How many imputations are really needed? Some practical clarifications of multiple imputation theory. Prevention Science, 8(3), 206-213. https://doi.org/10.1007/s11121-007-0070-9

Guarino, C. M., Santibañez, L., \& Daley, G. A. (2006). Teacher recruitment and retention: A review of the recent empirical literature. Review of Educational Research, 76(2), 173-208. https://doi.org/10.3102/00346543076002173

Hanfstingl, B. (2019). Lehrerpersönlichkeit: Kritische Würdigung und Ausblick [Teacher personality: critical appraisal and outlook]. In U. Steffens \& P. Posch (Eds.), Lehrerprofessionalität und Schulqualität. Grundlagen der Qualität von Schule 4 (pp. 97-110). Waxmann.

Helmke, A. (2012). Unterrichtsqualität und Lehrerprofessionalität: Diagnose, Evaluation und Verbesserung des Unterrichts [Teaching quality and teacher profes- 
sionalism: diagnosis, evaluation and improvement of teaching] (4th ed.). KlettKallmeyer.

Holland, J. L. (1997). Making vocational choices: A theory of vocational personalities and work environments (3rd ed.). Psychological Assessment Research.

Kaub, K., Karbach, J., Biermann, A., Friedrich, A., Bedersdorfer, H.-W., Spinath, F. M., \& Brünken, R. (2012). Berufliche Interessensorientierungen und kognitive Leistungsprofile von Lehramtsstudierenden mit unterschiedlichen Fachkombinationen [Vocational interests and cognitive ability of first-year teacher candidates as a function of selected study major]. Zeitschrift für Pädagogische Psychologie, 26(4), 233-249. https://doi.org/10.1024/1010-0652/a000074

Klusmann, U. (2013). Individual characteristics of prospective teachers. In M. Kunter, J. Baumert, W. Blum, U. Klusmann, S. Krauss, \& M. Neubrand (Eds.), Cognitive activation in the mathematics classroom and professional competence of teachers: Results from the COACTIV project (pp. 311-319). Springer. https://doi. org/10.1007/978-1-4614-5149-5_15

Klusmann, U., Trautwein, U., Lüdtke, O., Kunter, M., \& Baumert, J. (2009). Eingangsvoraussetzungen beim Studienbeginn: Werden die Lehramtskandidaten unterschätzt? [Cognitive and psychosocial characteristics upon entry into teacher training: Are teacher candidates underestimated?] Zeitschrift für Pädagogische Psychologie, 23(3-4), 265-278. https://doi.org/10.1024/1010-0652.23.34.265

König, J., Rothland, M., Darge, K., Lünnemann, M., \& Tachtsoglou, S. (2013). Erfassung und Struktur berufswahlrelevanter Faktoren für die Lehrerausbildung und den Lehrerberuf in Deutschland, Österreich und der Schweiz [Detection and structure of career choice factors for teacher training and the teaching profession in Germany, Austria and Switzerland]. Zeitschrift für Erziehungswissenschaft, 16, 533-577. https://doi.org/10.1007/s11618-013-0373-5

Krauss, S., Lindl, A., Schilcher, A., \& Tepner, O. (2017). Das Forschungsprojekt FALKO - ein einleitender Überblick [The FALKO research project - an introductory overview]. In S. Krauss, A. Lindl, A. Schilcher, M. Fricke, A. Göhring, B. Hofmann, ... J. Baumert (Eds.), FALKO: Fachspezifische Lehrerkompetenzen: Konzeption von Professionswissenstests in den Fächern Deutsch, Englisch, Latein, Physik, Musik, Evangelische Religion und Pädagogik: Mit neuen Daten aus der COACTIV-Studie (pp. 9-65). Waxmann.

Kristof-Brown, A. L., Zimmerman, R. D., \& Johnson, E. C. (2005). Consequences of individuals' fit at work: A meta-analysis of person-job, person-organization, person-group, and person-supervisor fit. Personnel Psychology, 58, 281-342. https://doi.org/10.1111/j.1744-6570.2005.00672.x

Kunter, M., Klusmann, U., Baumert, J., Richter, D., Voss, T., \& Hachfeld, A. (2013). Professional competence of teachers: Effects on instructional quality and student development. Journal of Educational Psychology, 105(3), 805-820. https://doi. org/10.1037/aoo32583

Latcheva, R., \& Davidov, E. (2019). Skalen und Indizes [Scales and indices]. In N. Baur \& J. Blasius (Eds.), Handbuch Methoden der empirischen Sozialforschung (2nd ed., pp. 893-905). Springer VS. https://doi.org/10.1007/978-3-658-21308-4_62

Li, Y., Yao, X., Chen, K., \& Wang, Y. (2013). Different fit perceptions in an academic environment: Attitudinal and behavioral outcomes. Journal of Career Assessment, 21(2), 163-174. https://doi.org/10.1177/1069072712466713

Leibniz Institute for Educational Trajectories. (2014). Starting Cohort 5: First-Year Students (SC5). SUF version 4.O.o. Codebook (en). Retrieved from https://www. neps-data.de/Portals/o/NEPS/Datenzentrum/Forschungsdaten/SC5/4-O-O/ SC5_4-0-o_Codebook_en.pdf

Leibniz-Institut für Bildungsverläufe e.V. (2014). Startkohorte 5: Studierende (SC5). SUF-Version 4.O.o. Codebook (de) [Starting Cohort 5: Students ( $\mathrm{SC}_{5}$ ). SUF-Version 
4.o.o. Codebook (de)]. Retrieved from https://www.neps-data.de/Portals/o/ NEPS/Datenzentrum/Forschungsdaten/SC5/4-O-O/SC5_4-O-O_Codebook_de.pdf

Lindl, A., \& Kloiber, H. (2017). FALKO-L: Modellierung und Messung domänenspezifischer Kompetenzen von Lateinlehrkräften [FALKO-L: Modeling and measuring domain-specific competencies of Latin teachers]. In S. Krauss, A. Lindl, A. Schilcher, M. Fricke, A. Göhring, B. Hofmann, ... J. Baumert (Eds.), FALKO: Fachspezifische Lehrerkompetenzen: Konzeption von Professionswissenstests in den Fächern Deutsch, Englisch, Latein, Physik, Musik, Evangelische Religion und Pädagogik: Mit neuen Daten aus der COACTIV-Studie (pp. 153-200). Waxmann.

Long, J. S., \& Freese, J. (2014). Regression models for categorical dependent variables using Stata (3rd ed.). Stata Press.

Lüdtke, O., Robitzsch, A., Trautwein, U., \& Köller, O. (2007). Umgang mit fehlenden Werten in der psychologischen Forschung [Handling of missing data in psychological research: Problems and solutions]. Psychologische Rundschau, 58(2), 103117. https://doi.org/10.1026/0033-3042.58.2.103

Mayr, J. (2014). Der Persönlichkeitsansatz in der Forschung zum Lehrerberuf. Konzepte, Befunde und Folgerungen [The personality approach in research on the teaching profession. Concepts, findings and conclusions]. In E. Terhart, $\mathrm{H}$. Bennewitz, \& M. Rothland (Eds.), Handbuch der Forschung zum Lehrerberuf (2nd ed., pp. 189-215). Waxmann.

Mayr, J., \& Neuweg, G. H. (2009). Lehrer/innen als zentrale Ressource im Bildungssystem: Rekrutierung und Qualifizierung [Teachers as the central resource in the education system: Recruitment and qualification]. In W. Specht (Ed.), Nationaler Bildungsbericht Österreich 2009. Band 2: Fokussierte Analysen bildungspolitischer Schwerpunktthemen (pp. 99-119). Bundesministerium für Unterricht, Kunst und Kultur.

Nagy, G. (2007). Berufliche Interessen, kognitive und fachgebundene Kompetenzen: Ihre Bedeutung für die Studienfachwahl und die Bewährung im Studium [Vocational interests, cognitive and scholastic abilities: Their role in choice of major and success at university] (Dissertation). Freie Universität Berlin.

Neugebauer, M. (2013). Wer entscheidet sich für ein Lehramtsstudium - und warum? Eine empirische Überprüfung der These von der Negativselektion in den Lehrerberuf [Who chooses to study education - and why? An empirical examination of the thesis of negative selection into the teaching profession]. Zeitschrift für Erziehungswissenschaft, 16(1), 157-184. https://doi.org/10.1007/s11618-0130343-y

Rammstedt, B., \& John, O. P. (2007). Measuring personality in one minute or less: A 10-item short version of the Big Five Inventory in English and German. Journal of Research in Personality, 41, 203-212. https://doi.org/10.1016/j.jrp.2006.02.001

Retelsdorf, J., \& Möller, J. (2012). Grundschule oder Gymnasium? Zur Motivation ein Lehramt zu studieren [Primary or secondary school? On the motivation for choosing teacher education]. Zeitschrift für Pädagogische Psychologie, 26(1), 5-17. https://doi.org/10.1024/1010-0652/a000056

Roloff, J., Klusmann, U., Lüdtke, O., \& Trautwein, U. (2020). The predictive validity of teachers' personality, cognitive and academic abilities at the end of high school on instructional quality in Germany: A longitudinal study. AERA Open, 6(1), 1-17. https://doi.org/10.1177/2332858419897884

Roloff Henoch, J., Klusmann, U., Lüdtke, O., \& Trautwein, U. (2015). Who becomes a teacher? Challenging the "negative selection" hypothesis. Learning and Instruction, 36, 46-56. https://doi.org/10.1016/j.learninstruc.2014.11.005

Rothland, M. (2014). Wer entscheidet sich für den Lehrerberuf? Herkunfts-, Persönlichkeits- und Leistungsmerkmale von Lehramtsstudierenden [Who chooses to become a teacher? Family background, personality and performance characteristics 
of student teachers]. In E. Terhart, H. Bennewitz, \& M. Rothland (Eds.), Handbuch der Forschung zum Lehrerberuf (2nd ed., pp. 319-348). Waxmann.

Schafer, J. L., \& Graham, J. W. (2002). Missing data: Our view of the state of the art. Psychological Methods, 7(2), 147-177. https://doi.org/10.1037/1082-989X.7.2.147

Spinath, B., van Ophuysen, S., \& Heise, E. (2005). Individuelle Voraussetzungen von Studierenden zu Studienbeginn: Sind Lehramtsstudierende so schlecht wie ihr Ruf? [Individual prerequisites of students at the beginning of their studies: Are student teachers as bad as their reputation?] Psychologie in Erziehung und Unterricht, 3, 186-197.

Steinwede, J., \& Aust, F. (2012). Methodenbericht. NEPS Startkohorte 5 - CATIHaupterhebung Herbst 2010 [Technical report. NEPS Starting Cohort 5 - CATI main study fall 2010]. Institut für angewandte Sozialwissenschaft. Retrieved from https://www.neps-data.de/Portals/o/NEPS/Datenzentrum/Forschungsdaten/ SC5/3-O-O/NEPS_FieldReport_SC5_W1_CATI.pdf

Trapmann, S., Hell, B., Weigand, S., \& Schuler, H. (2007). Die Validität von Schulnoten zur Vorhersage des Studienerfolgs - eine Metaanalyse [The validity of school grades for academic achievement - A meta-analysis]. Zeitschrift für Pädagogische Psychologie, 21(1), 11-27. https://doi.org/10.1024/1010-0652.21.1.11

Watt, H. M. G., Richardson, P. W., Klusmann, U., Kunter, M., Beyer, B., Trautwein, U., \& Baumert, J. (2012). Motivations for choosing teaching as a career: An international comparison using the FIT-Choice scale. Teaching and Teacher Education, 28, 791-805. https://doi.org/10.1016/j.tate.2012.03.003

Weber, K. E., Czerwenka, K., \& Kleinknecht, M. (2019). Professionalität von Lehrkräften. Theoretische Konzepte und aktuelle empirische Befunde der Professionalisierungsforschung [Teacher professionalism. Theoretical concepts and current empirical findings of professionalization research]. In U. Steffens \& P. Posch (Eds.), Lehrerprofessionalität und Schulqualität. Grundlagen der Qualität von Schule 4 (pp. 39-68). Waxmann.

White, I. R., Royston, P., \& Wood, A. M. (2011). Multiple imputation using chained equations: Issues and guidance for practice. Statistics in Medicine, 30(4), 377399. https://doi.org/10.1002/sim.4067

Wigfield, A., \& Eccles, J. S. (2000). Expectancy-value theory of achievement motivation. Contemporary Educational Psychology, 25(1), 68-81. https://doi.org/10. 1006/ceps.1999.1015

Wohlkinger, F., Blumenfelder, A. R., Bayer, M., von Maurice, J., Ditton, H., \& Blossfeld, H.-P. (2019). Measuring motivational concepts and personality aspects in the National Educational Panel Study. In H.-P. Blossfeld \& H.-G. Roßbach (Eds.), Education as a lifelong process: The German National Educational Panel Study (NEPS) (pp. 155-169). Springer VS. https://doi.org/10.1007/978-3-658-23162-o_9

Würfl, A. (2013). Zusammenhang von Persönlichkeitseigenschaften und Risikomerkmalen bei Lehramtsstudierenden [Relationship of personality traits and risk characteristics in student teachers] (Diplomarbeit). Universität Wien.

Yang, Y., \& Green, S. B. (2011). Coefficient alpha: A reliability coefficient for the 21st century? Journal of Psychoeducational Assessment, 29(4), 377-392. https://doi. org/10.1177/0734282911406668

Zinn, S., Aßmann, C., Steinhauer, H. W., \& Schönberger, B. (2016). Weighting the student sample of the National Educational Panel Study (Wave 1 to 6): Technical report on SUF version 6-O-O. Retrieved from https://www.neps-data.de/Portals/o/ NEPS/Datenzentrum/Forschungsdaten/SC5/6-O-O/SC5_6-O-O_Weighting.pdf

Zumwalt, K., \& Craig, E. (2008). Who is teaching? Does it matter? In M. CochranSmith, S. Feiman-Nemser, D. J. McIntyre, \& K. E. Demers (Eds.), Handbook of research on teacher education: Enduring questions and changing contexts (3rd ed., pp. 404-423). Routledge. 